\title{
Statistical Analysis of the Factors Influencing Consumer Use of E85
}

Subcontract Report NREL/SR-540-42984 July 2008

P. Bromiley

University of California, Irvine Irvine, California

T. Gerlach, K. Marczak, M. Taylor, and

L. Dobrovolny

American Lung Association of the Upper Midwest

Saint Paul, Minnesota 


\section{Statistical Analysis of the Factors Influencing Consumer Use of E85}

P. Bromiley

University of California, Irvine

Irvine, California

T. Gerlach, K. Marczak, M. Taylor, and

L. Dobrovolny

American Lung Association of the Upper Midwest

Saint Paul, Minnesota

NREL Technical Monitor: Paul Bergeron

Prepared under Subcontract No. AEV-7-77396-01

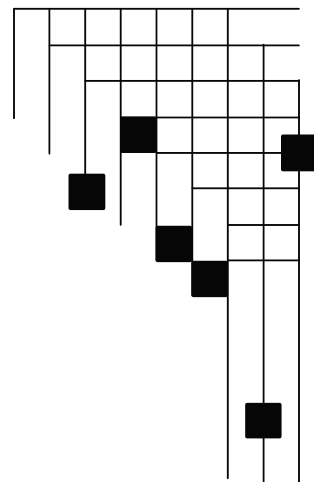




\section{NOTICE}

This report was prepared as an account of work sponsored by an agency of the United States government. Neither the United States government nor any agency thereof, nor any of their employees, makes any warranty, express or implied, or assumes any legal liability or responsibility for the accuracy, completeness, or usefulness of any information, apparatus, product, or process disclosed, or represents that its use would not infringe privately owned rights. Reference herein to any specific commercial product, process, or service by trade name, trademark, manufacturer, or otherwise does not necessarily constitute or imply its endorsement, recommendation, or favoring by the United States government or any agency thereof. The views and opinions of authors expressed herein do not necessarily state or reflect those of the United States government or any agency thereof.

Available electronically at http://www.osti.gov/bridge

Available for a processing fee to U.S. Department of Energy and its contractors, in paper, from:

U.S. Department of Energy

Office of Scientific and Technical Information

P.O. Box 62

Oak Ridge, TN 37831-0062

phone: 865.576 .8401

fax: 865.576 .5728

email: mailto:reports@adonis.osti.gov

Available for sale to the public, in paper, from:

U.S. Department of Commerce

National Technical Information Service

5285 Port Royal Road

Springfield, VA 22161

phone: 800.553 .6847

fax: 703.605.6900

email: orders@ntis.fedworld.gov

online ordering: http://www.ntis.gov/ordering.htm

This publication received minimal editorial review at NREL 


\section{Acknowledgements}

This work was funded by the National Renewable Energy Laboratory (NREL) under Contract No. AEV-7-77396-01. We particularly appreciate the support of Paul Bergeron and Michael

Helwig of NREL; Vicki Putsche, formerly of NREL; and Stacy Miller and Theresa Staples at the Minnesota Department of Commerce. 


\section{Executive Summary}

In 1997, eight E85 (85\% ethanol; 15\% gasoline) fuel pumps were installed at separate retail fuel stations in Minnesota to provide high-blend ethanol fuel to flexible fuel vehicle (FFV) owners. FFVs capable of utilizing gasoline, E85, or any mixture of the two, were beginning to be mass produced by vehicle manufacturers and distributed through fleet and retail sales nationwide. These state-level E85 efforts were part of larger federal and state policies and programs promoting the use of alternative transportation fuels to displace traditional gasoline and diesel fuel, which continue today. By the end of 2006, there were approximately 300 E85 fuel station locations and over 125,000 FFVs in Minnesota. The amount of E85 fuel being utilized in the state was estimated at approximately 18 million gallons annually.

Evaluating the sales patterns of E85 retail outlets can provide important information about consumer behavior regarding E85, locating future E85 fueling infrastructure, and developing future alternative fuel policies and programs. We used multivariate statistical analyses to estimate the significance of factors that influence the volume of E85 fuel sales to the general public in Minnesota from 1997 to 2006, including the gallon price of E85 and gasoline, FFV vehicle ownership, population demographics, and other variables.

The analysis determined that the following factors increase E85 sales at retail outlets:

1. Price Differential. The price difference between E85 and regular gasoline has a substantial effect on E85 sales. Declining E85 prices and increasing gasoline prices both increase the volume of E85 sold at a station, although, the latter has a greater influence and the price difference has a greater effect at higher relative prices.

2. Station Location. Stations located in eight Minneapolis-Saint Paul metropolitan area counties had higher E85 volume sales than those in other counties.

3. FFV Volume. There was a positive influence on $\mathrm{E} 85$ sales from the number of flexible fuel vehicles located in the same zip code as the station.

4. E85 Signage. E85 stations with visible price sign marquees experience increased E85 sales volumes than those without signs.

5. Non-major Branding. E85 stations that are branded with non-major branding, (e.g., Speedway, SuperAmerica, Kwik Trip, Cenex, Holiday) sell more E85.

6. Station Longevity. Stations which have sold E85 longer have greater E85 sales volumes.

7. Supply and Demand. Stations that are located in a zip code with fewer stations selling E85 had increased sales volumes.

Strategies for station owners to increase E85 consumption include:

- Keeping E85 price competitive with regular gasoline through

- direct supply arrangements with ethanol plants or purchase aggregation cooperatives

- long-term pricing that maintains a specific monetary or percentage difference below regular gasoline

- Locating E85 pumps at stations in areas with high FFV populations

- Locating E85 pumps at stations in metropolitan areas

- Utilizing an E85 price sign

- Selling non-major brand fuels. 


\section{Table of Contents}

Acknowledgements ....................................................................................................... iii

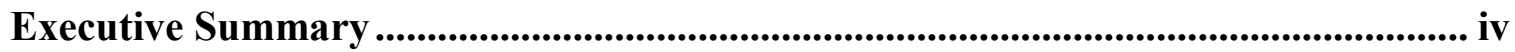

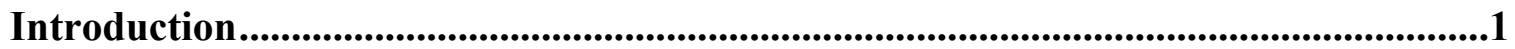

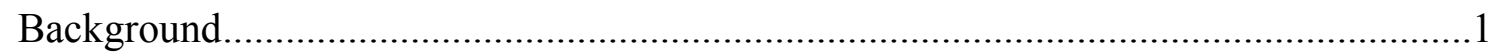

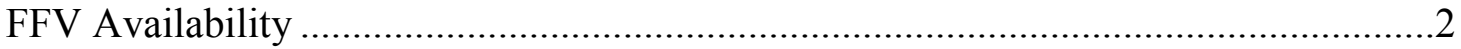

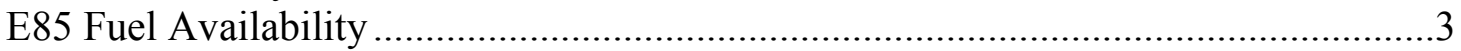

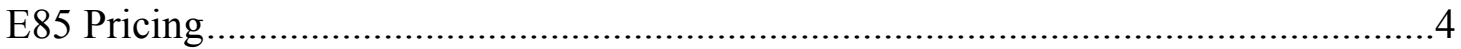

The Influence on Street Price and Sales.....................................................................6

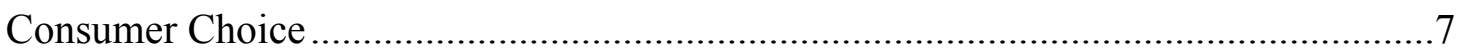

E85 Consumption in Minnesota.........................................................................

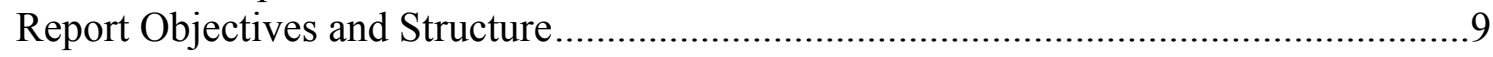

Data, Variables, and Methods.....................................................................................10

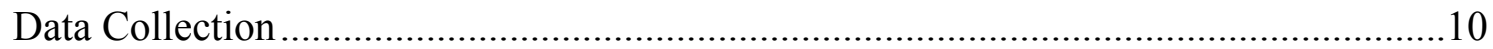

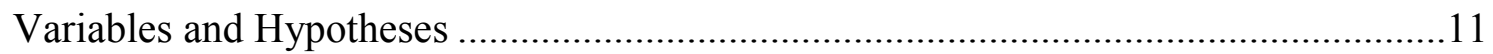

Dependent Variable: Volume of E85 …………………….....................................11

Explanatory/Independent Variables ......................................................................11

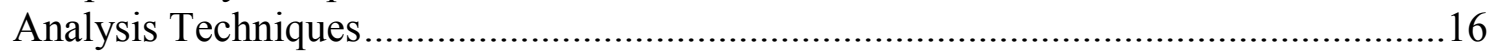

Multivariate Analysis Results ............................................................................................18

Basic Analysis of Monthly E85 Volumes …………...........................................18

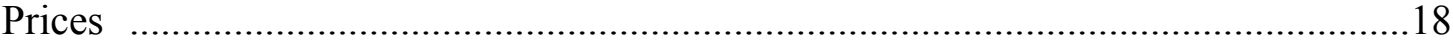

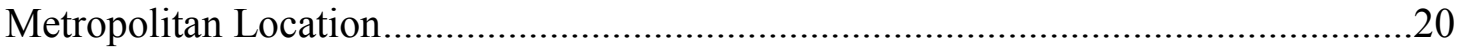

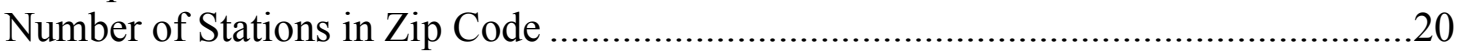

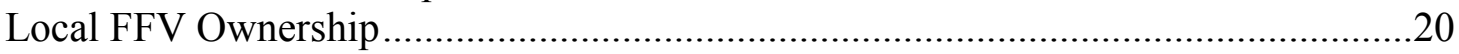

Green Vote

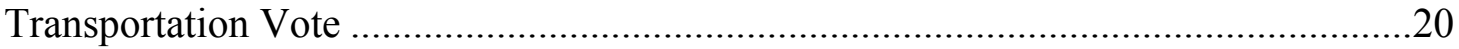

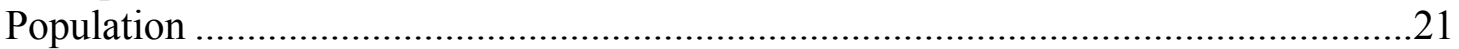

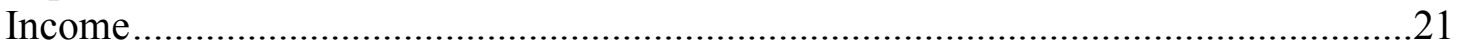

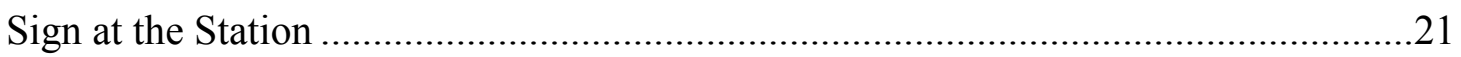

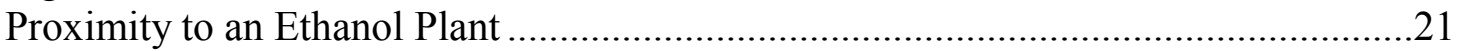

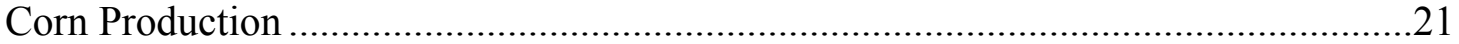

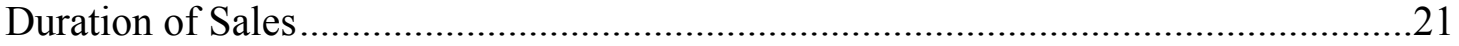

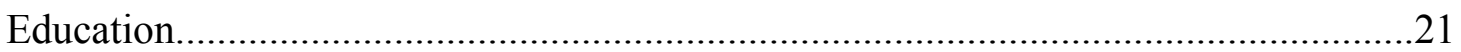

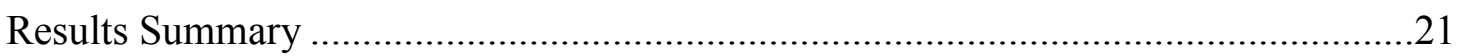

Brand Analysis of Monthly E85 Volumes …………...........................................21

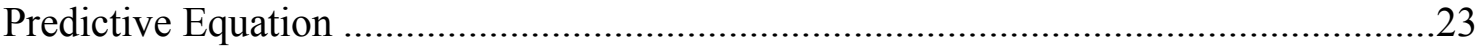

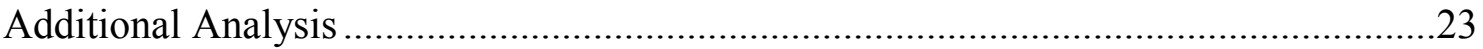

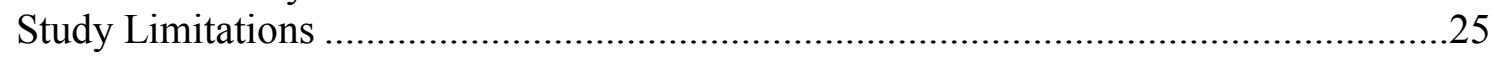

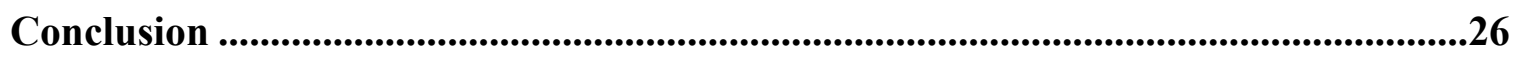




\section{Introduction}

\section{Background}

Minnesota has a significant history of promoting ethanol production and use, including supplyside incentives beginning in the 1980's, and demand-side requirements beginning in the 1990's. Currently, Minnesota provides a payment of $\$ 0.13$ per gallon for ethanol produced at qualifying ethanol plants, and was the first state in the United States with a statewide $10 \%$ ethanol blending requirement for nearly all gasoline fuel. ${ }^{1,2}$ At present, there are 17 ethanol plants in Minnesota with production capacities of about nearly 680 million gallons, and over 250 million gallons of fuel ethanol ${ }^{3}$ are being blended as an oxygenate ${ }^{4}$ in Minnesota's motor vehicle gasoline. ${ }^{5,6}$

To more substantially displace traditional gasoline and diesel fuel options in individual vehicles, the federal Energy Policy Act of 1992 (EPAct) placed an emphasis on promoting dedicated alternative transportation fuels, such as high percentage or pure blends of ethanol, natural gas, propane, and electricity. A combination of programs, requirements, and incentives promote alternative fuel vehicle (AFV) production by vehicle manufacturers, adoption of AFVs by federal and state vehicle fleets, and the development of alternative fueling infrastructure, to achieve the overall goal of displacing petroleum transportation use. Ethanol fuel is designated as a qualifying alternative fuel under EPAct when it is blended with gasoline at a $70 \%$ to $85 \%$ ethanol, and is marketed as E85.

E85 is unique among alternative fuels in that the primary target market is retail consumers rather than fleet vehicles. For flexible fuel vehicle (FFV) owners (described in greater detail, below), E85 essentially acts as a gasoline substitute.

Consumer utilization of E85 fuel depends on four elements.

1. FFV Availability. The consumer owns an FFV.

2. E85 Fuel Availability. The consumer has station access to E85.

3. E85 Pricing. E85 fuel is priced competitively with regular gasoline.

4. Consumer Choice. Consumer chooses to purchase E85 over gasoline.

\footnotetext{
${ }^{1}$ The ethanol production incentive is not available to new facilities and is set to expire for all facilities in 2010 . Minnesota House of Representatives, House Research, http://www.house.leg.state.mn.us/hrd/issinfo/ssethnl.htm. ${ }^{2}$ Originally an oxygenate requirement, the $10 \%$ ethanol requirement has since been targeted to increase to $20 \%$ by 2013, subject to a U.S. Environmental Protection Agency fuel waiver and other conditions, unless met voluntarily through E85 and E10 sales by 2010.

${ }^{3}$ The term "fuel ethanol" is used in this paper to describe ethanol used in low-percentage blends as an oxygenate as opposed to the high-percentage blend E85, in which ethanol functions as an alternative transportation fuel.

${ }^{4} \mathrm{~A}$ fuel oxygenate is an additive in gasoline which reduces emissions of carbon monoxide and volatile organic compounds.

${ }^{5}$ Minnesota Department of Agriculture, http://www.mda.state.mn.us/renewable/ethanol.

${ }^{6}$ U.S. Energy Information Administration, http://tonto.eia.doe.gov/state/state energy profiles.cfm?sid=MN.

${ }^{7}$ E85's ethanol levels vary by season, from a low of $70 \%$ in winter to a high of $85 \%$ in summer, to preemptively address fuel volatility and cold-weather operational issues. The changes occur according to ASTM D 5798-99 "Standard Specification for Fuel Ethanol for Automotive Spark-Ignition Engines." For more information, see the "Handbook for Handling, Storing, and Dispensing E85" (U.S. Department of Energy, July 2006).
} 


\section{FFV Availability}

FFVs are capable of utilizing gasoline, E85, or any mixture of the two. Consumers can seamlessly fuel their FFVs with gasoline one day and E85 the next. Ethanol has lower energy content than gasoline, and the fuel flexibility in an FFV comes at the cost of reduced fuel economy. ${ }^{8}$ The flexible fuel capability is either an option on designated models, or more commonly, is standard equipment on a vehicle model in particular production years. ${ }^{9}$

Corporate Average Fuel Economy (CAFE) incentives have been very effective at increasing vehicle manufacturers' production of FFVs. For each flexible fuel vehicle produced, manufacturers receive a 1.25 credit multiplier against the vehicle's calculated fuel efficiency rating, such that a $20 \mathrm{mpg}$ vehicle is calculated as $25 \mathrm{mpg}$ for the CAFE standard. ${ }^{10}$ The choice and availability of E85 models are at the sole discretion of vehicle manufacturers. Some E85 vehicle models have a consecutive multi-year history of E85 capability, while others are only available in a single year model. Manufacturers have generally chosen larger vehicles with fuel efficiency below their average CAFE calculation for E85 capabilities.

The complexity of converting an existing vehicle design to include flexible fuel capability ranges across manufacturers, but includes replacing minor components to ensure materials compatibility with high-blend ethanol fuels and system programming changes for adjusting to fuel and combustion characteristics. The incremental cost of producing a vehicle with the FFV system is estimated at less than $\$ 100$ to several hundred dollars depending on the model, system design, number of units produced, and other factors. ${ }^{11}$ Gasoline-only vehicles operated on E85 may experience some performance loss in the short-term and degradation of internal components over the longer term. Typically, a single misfueling event will not permanently damage a non-E85 vehicle.

It is very likely that a consumer who purchased an FFV in the 1990s and late 2000s was unaware of the flexible fuel capability. The minimum indicator was a small note in the vehicle manual and on the fuel lid. Vehicle manufacturers were initially reticent to advertise the flexible fuel capability because they did not want their products to appear different than a competing brand and E85 fuel was not widely available at that time. This has since changed with several American manufacturers now clearly identifying their FFV models and using the flex-fuel system as a selling point in their advertising and government relations efforts.

In 1997, FFVs were beginning to be mass produced and few models were available. By the end of 2006, the number of models had expanded to 30 and more than 125,000 FFVs were operating in Minnesota. ${ }^{12}$

\footnotetext{
${ }^{8}$ A gallon of ethanol roughly equals two-thirds of the energy content of a gallon of gasoline. A dedicated E85 vehicle, optimized to ethanol combustion, could substantially reduce the energy content penalty, although at the cost of fuel flexibility.

${ }^{9}$ A complete list of current and past E85 vehicle models is available at www.CleanAirChoice.org.

${ }^{10}$ It is worth noting that this provision is not without controversy as to its effectiveness in displacing petroleum fuels. FFVs are broadly distributed across the country, where E85 fuel may or may not be available and utilization rates of E85 relative to FFV ownership are currently quite low.

${ }^{11}$ Tim Gerlach, American Lung Association of the Upper Midwest (personal communication).

${ }^{12}$ R.L. Polk, VIN\# search for Minnesota FFVs, 12/2006.
} 


\section{E85 Fuel Availability}

E85 fuel is dispensed through dedicated, newly installed dispensers or through equipment converted from gasoline or diesel use. Similar to vehicle conversions, E85 fueling equipment requires that certain parts are compatible with high-blend ethanol fuels and that proper tank cleaning and fuel handling methods are followed. ${ }^{13}$

In late 1997, the installation and operation of eight E85 fuel pumps began at separate retail fuel stations in Minnesota with forgivable loans from the U.S. Department of Energy, administered by the Minnesota Department of Commerce (MNDOC). A portion of the loan was de-obligated for each year that a station owner sold E85 over a two- to five-year period, such that at the end of the time period, the loan was completely forgiven.

In 1998, the Minneapolis-Saint Paul metropolitan area (Twin Cities) was specifically designated as a national E85 pilot market by the U.S. Department of Energy (DOE), in order to concentrate resources on E85 development in specific markets. ${ }^{14}$ The American Lung Association of the Upper Midwest (ALAUM) has managed the Minnesota E85 Pilot Project since that time, utilizing the link to outdoor air quality in their support of the project. ${ }^{15}$ ALAUM activities include educating consumers about the benefits of E85; coordinating the E85 station grant program; performing the media and public relations tasks; and partnering with federal, state, private, and non-governmental organizations to advance the overall program.

In a similar pattern to vehicle manufacturer reticence, the process of convincing fuel station owners to install and manage E85 fuel pumps was more difficult in the late 1990s and early 2000s, requiring longer negotiations with individual stations or fuel chains and larger federal, state, and private funding packages for station conversion costs. Ideally, the E85 dispenser is located under the main island canopy, utilizes the same credit card transaction equipment as the other fuels, and shares signage equal to other fuel products. More commonly in the early development years, E85 might have been located behind or to the side of the main store and required the customer to ask the station attendant to start the pump. Today, siting E85 on or near the main fuel island is the norm.

In recent years as gasoline price and price volatility have increased and geopolitical oil sourcing issues have become more prevalent, the interest and willingness of station owners to provide E85 has improved significantly, requiring less funding assistance on a per station basis. By the end of 2006, the number of E85 outlets in Minnesota had grown to approximately 300 operating stations - more than twice the next closest state. ${ }^{16}$

\footnotetext{
${ }^{13}$ For more information, see the "Handbook for Handling, Storing, and Dispensing E85" (U.S. Department of Energy, July 2006).

${ }^{14}$ Chicago and Denver were also designated as E85 pilot markets.

${ }^{15}$ Other members of the Minnesota Clean Air Choice E85 Pilot Project team: Minnesota Corn Growers Association, General Motors Corporation, Minnesota Department of Agriculture, Minnesota Department of Commerce, National Ethanol Vehicle Coalition, and U.S. Department of Energy Clean Cities Program.

${ }^{16}$ U.S. Department of Energy, Alternative Fuels Data Center, www.eere.energy.gov/afdc.
} 


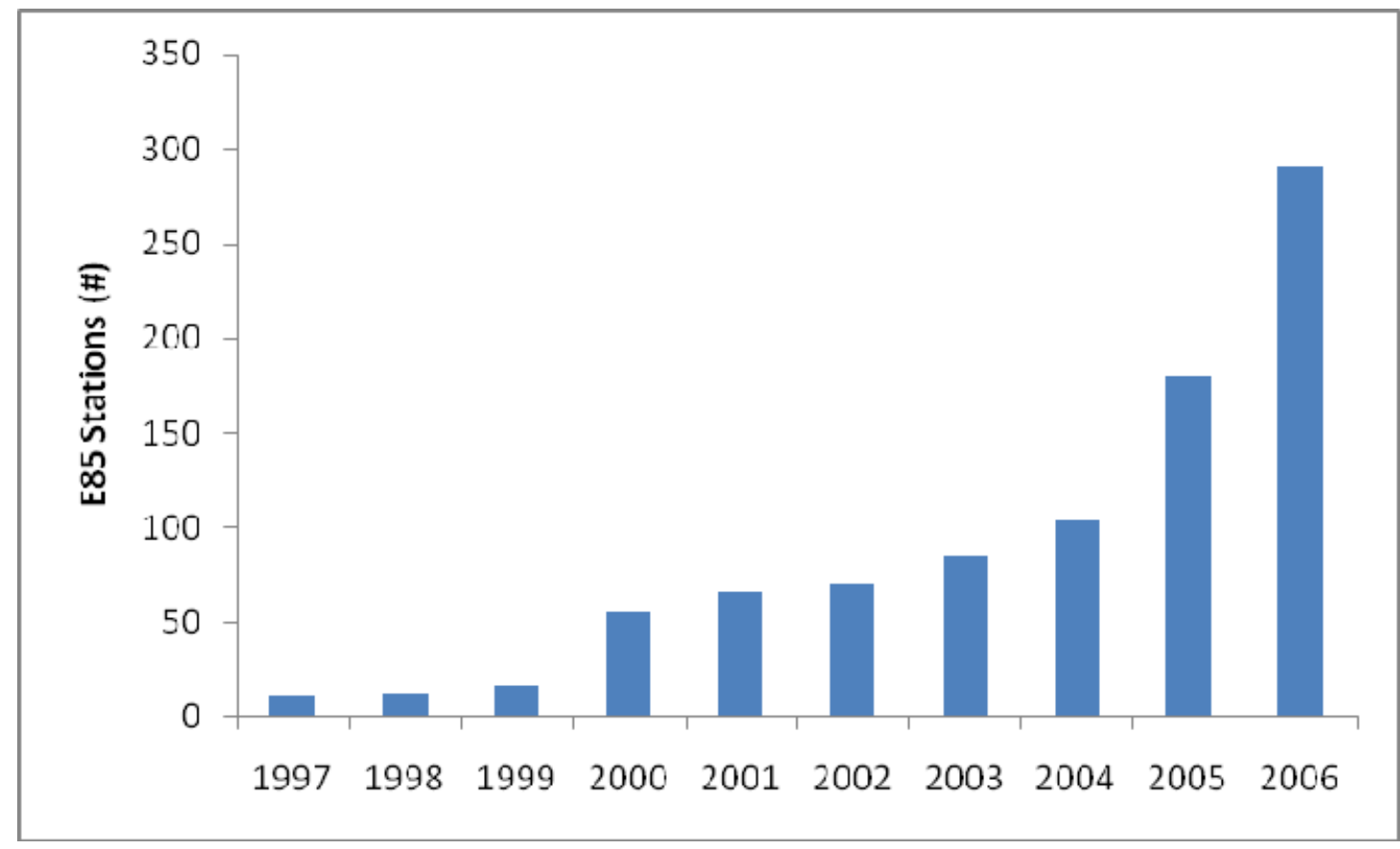

Figure 1. Minnesota E85 station development, 1997-2006. Source: Minnesota Department of Commerce; Minnesota Clean Air Choice Team

\section{E85 Pricing}

E85 pricing is not only a function of supply and demand, but also the relative volumes and transaction costs compared to petroleum products. When considering E85 pricing, it is important to remember both E85 and fuel ethanol's place in the broader gasoline market, and relative to each other. Nationally, an estimated 50 to 60 million gallons of E85 were sold in the United States in $2006,{ }^{17}$ which is less than $1 \%$ of the 5.6 billion gallons of ethanol produced in North America in $2006 .{ }^{18}$ In turn, fuel ethanol currently comprises about $4 \%$ of the national gasoline fuel market of 140 billion gallons per year, and is just beginning to gain availability in certain markets at mainstream fuel terminals around the United States. ${ }^{19}$ At this early stage of development, E85 is not a high priority of major companies handling and supplying fuels for the wholesale market.

Historically, the wholesale market price for denatured ethanol (without consideration of the federal blenders tax credit) has been either at, or higher than, regular gasoline. However differences vary over time and by regional markets, and a dramatic increase in U.S. production and use will undoubtedly influence future market prices. Similar to petroleum markets, the price of ethanol mirrors the price of gasoline because the market price of ethanol is based on its supply and demand as a fuel commodity, not the cost of ethanol production (Figure 2). Since ethanol is a gasoline additive (or replacement component), it is effectively priced from the gasoline price basis. Recently, however, ethanol over- and under-supply has caused a deviation from this gasoline price-following trend.

\footnotetext{
${ }^{17}$ Personal communications, Gerlach at American Lung Association of the Upper Midwest; Phil Lampert and Roger Listenberger at National Ethanol Vehicle Coalition.

18 "Ethanol Experiences Growing Pains" by Michael Shirek, Ethanol Producer Magazine, Dec. 2007, p.118-125.

${ }^{19}$ Transportation Energy Data Book: Edition 26-2007, USDOE-EERE, Table 2.11; calculation based on 1995-2005 average annual percentage change and backing out of ethanol use.
} 
Ethanol pricing is also influenced by tax credits. When accounting for the Volumetric Ethanol Excise Tax Credit (VEETC), the wholesale ethanol price drops to below, or similar to, the wholesale price range of regular gasoline. However, it can vary by year based on supply and demand (Figure 2). ${ }^{20}$ Wholesale prices will not necessarily be mirrored in the actual retail price, due in part to the immature distribution and volumes of the ethanol industry in general, and E85 stations in particular. While fuel ethanol blends with gasoline may be found today at a growing number of petroleum terminals around the United States (where higher volumes and standard distribution channels can reduce costs), E85 is not yet a mainstream product.

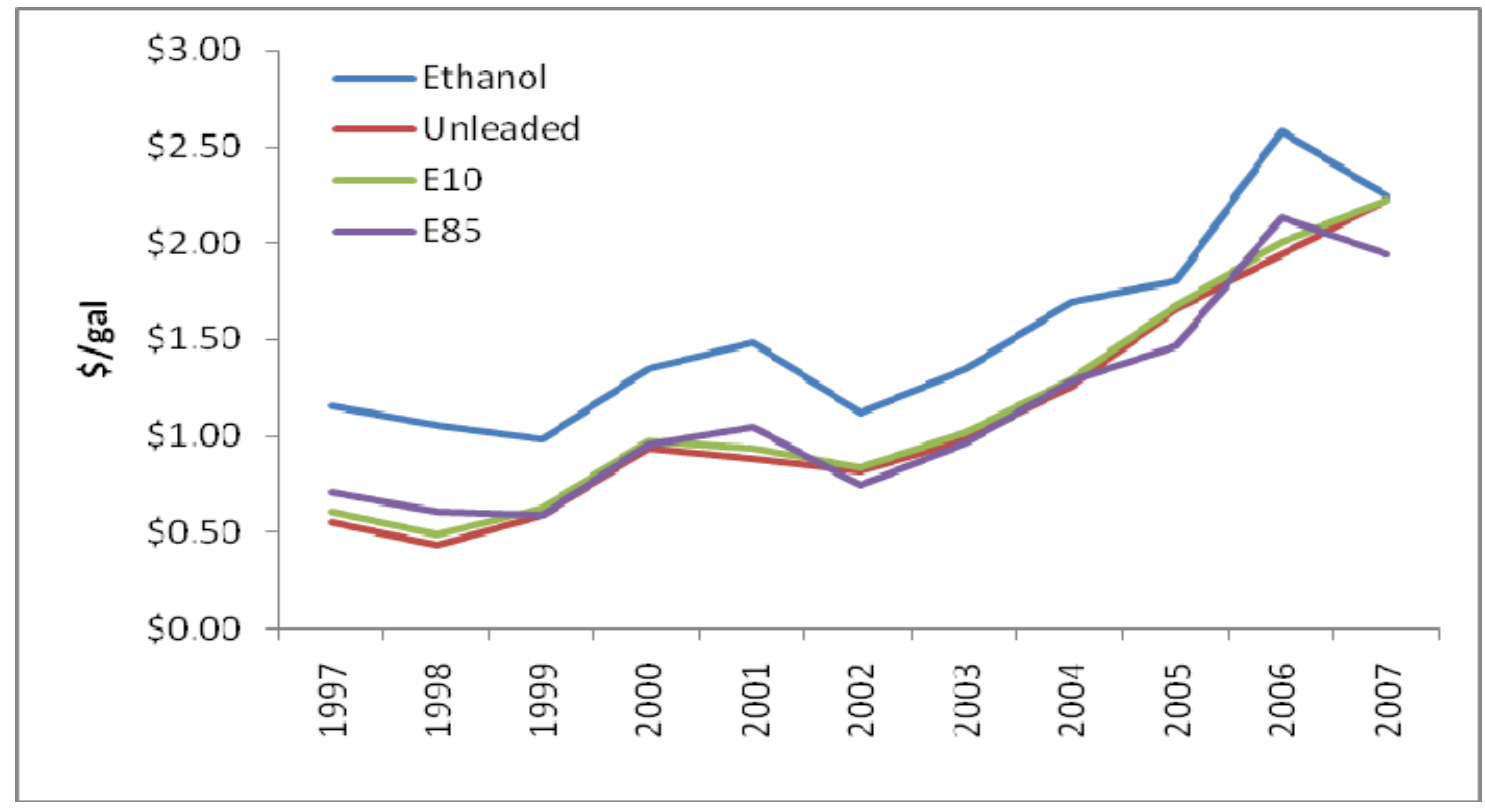

Figure 2. Ethanol and Gasoline Rack Prices in Omaha, NE; Estimated E10 and E85 Rack Prices After Federal Tax Credits. Source: Nebraska Energy Office http://www.neo.ne.gov/statshtml/66.html

Ethanol and gasoline are blended and delivered as E85 to stations in one of three primary ways. Each option influences costs for the stations and pump prices for consumers:

- Option 1: Gasoline terminal to station. In this option the E85 price is based on the potentially volatile spot market price of that day. This tends to be the least competitive choice since the day-to-day ethanol spot market price is set by the petroleum terminal company based on demand. In order to ensure coverage for contracted customers when supplies are

\footnotetext{
${ }^{20}$ In 2005, the VEETC replaced the existing federal ethanol excise tax credit. Prior to 2005, utilizing the full extent of ethanol tax credit was difficult for certain retail suppliers, but the VEETC tax policy changes have streamlined the process and applicability. Today, any company blending denatured ethanol into finished fuels receives an incentive that is based on a reduction of the amount of federal excise (road) tax owed on the ethanol-blended fuels. This is often referred to as the $\$ .51$ per gallon credit. For example, if ABC Oil Company sells $10 \%$ ethanol (E10), the tax owed by the company to the federal government on each gallon of E10 is reduced from $\$ .184$ to $\$ .133$ (10\% of the $\$ .51$ credit). For each gallon of E85 sold, the company would reduce its overall excise tax liability by $\$ .35$ to $\$ .43$. This is estimated by taking the $\$ .51$ credit and multiplying it by the seasonally adjusted denatured ethanol blend of $70 \%$ (winter E70) or $85 \%$ (summer E85).
} 
tight, it is common practice in the fuels industry to "back away" spot market customers by raising the price.

- Option 2: Ethanol plant to station. In this supply arrangement the E85 price is based on a longer term agreement between an ethanol plant and local stations. This requires the ethanol plant to install blending equipment and to take on the fiscal structure and staffing necessary for tasks outside its normal business operations. This tends to be a very competitive option for stations within a reasonable distance of a plant or for those willing to participate in "milk run" supply arrangements by which a supply truck stops at a series of E85 outlets.

- Option 3: Ethanol plant to intermediary to station. In this situation the E85 price is based on a longer term agreement between one or more ethanol plants, or their marketing representative, and the station. Typically, a local fuel transport company or "jobber" is used as an intermediary between the plant and station for the purposes of storing, supply agreements, and trucking to stations. This can be a very competitive option for stations and has the added benefit of allowing for wider or even regional-national distribution networks to develop, since larger companies tend to have ethanol supply at larger fuel terminals throughout the nation. However, if the ethanol supply shifts to cover the primary, low-blend market, it may be problematic in times of high ethanol demand.

Partially as a result of these different supply arrangements, E85 pricing is highly variable between stations. Retail E85 prices generally average less than regular unleaded 87-octane gasoline, but vary considerably depending on the station's ability to acquire competitive product and their desire to price it aggressively (Table 1). Certain brands or stations may have a longterm policy to price E85 less per gallon than gasoline (e.g. $\$ .40$ or $15 \%$ less than a posted gasoline price), regardless of the actual E85 cost, while other stations directly correlate E85 price to cost, which under some conditions, can be higher than gasoline.

Table 1. 2006 E85 Station Prices in Minnesota

\begin{tabular}{|l|l|l|l|l|}
\hline Month & E85 High & E85 Low & E85 Avg. & Regular \\
\hline January & $\$ 2.32$ & $\$ 1.50$ & $\$ 1.83$ & $\$ 2.23$ \\
\hline February & $\$ 2.32$ & $\$ 1.50$ & $\$ 1.81$ & $\$ 2.17$ \\
\hline March & $\$ 2.41$ & $\$ 1.50$ & $\$ 2.05$ & $\$ 2.42$ \\
\hline April & $\$ 2.76$ & $\$ 1.64$ & $\$ 2.29$ & $\$ 2.67$ \\
\hline May & $\$ 3.04$ & $\$ 1.65$ & $\$ 2.31$ & $\$ 2.74$ \\
\hline June & $\$ 2.98$ & $\$ 1.52$ & $\$ 2.38$ & $\$ 2.81$ \\
\hline July & $\$ 3.41$ & $\$ 2.32$ & $\$ 2.55$ & $\$ 2.95$ \\
\hline August & $\$ 3.33$ & $\$ 1.66$ & $\$ 2.50$ & $\$ 2.94$ \\
\hline September & $\$ 3.33$ & $\$ 1.66$ & $\$ 1.97$ & $\$ 2.34$ \\
\hline October & $\$ 2.10$ & $\$ 1.63$ & $\$ 1.79$ & $\$ 2.16$ \\
\hline November & $\$ 2.26$ & $\$ 1.68$ & $\$ 1.83$ & $\$ 2.18$ \\
\hline December & $\$ 2.75$ & $\$ 1.71$ & $\$ 1.85$ & $\$ 2.22$ \\
\hline
\end{tabular}

Source: Minnesota Department of Commerce "E85 Station Report," available at www.commerce.state.mn.us.

\section{The Influence on Street Price and Sales}

Three E85 station examples are presented below to illustrate the variability in E85 pricing due to different supply arrangements and other variables, including location, advertising, and duration 
of sales. Two of these outlets are located in the same community and have relatively similar traffic patterns, but only one has a price sign for E85. During the period for which data are available, Station A was supplied by Option 3 (intermediary) above, while Station B was supplied via a method similar to Option 1 (terminal spot market). Station $\mathrm{C}$ is located in an entirely different town and is also supplied by Option 1.

Station $\mathbf{A}$ is on a busy roadway near an interstate highway in a suburban setting. The station has been in operation for more than seven years and added a street-visible price sign for E85 several years ago. Its parent company, a well-known regional brand, negotiated an ethanol-for-E85 supply arrangement with a large ethanol marketing group. This allows the company to maintain an E85-to-gasoline price differential when E85 is approximately $15 \%$ to $20 \%$ less than gasoline at Station $\mathrm{A}$ and its other E85 outlets.

- Average monthly E85 sales (2006): At or less than 30,000 gallons

- Highest summer sales during summer months (2006): At or less than 40,000 gallons

Station B is located at the intersection of two busy roadways near an industrial area in the same suburban setting as Station A. The station has been in operation for more than seven years and does not have a street-visible price sign for E85. Its parent company, a well-known regional brand, had not negotiated an E85-specific supply agreement at the time these data were collected and generally set the E85 price point at an arbitrary point less than its gasoline price. Most often, this was $\$ .20$ below the posted gasoline price at the station. (Note: this company has since improved its supply situation, added several new E85 outlets, and grown its E85 sales significantly. Due to a city ordinance, this site still does not have an E85 price sign.)

- Average monthly E85 sales (2006): At or less than 8,000 gallons

- Highest (summer) monthly sales (2006): At or less than 10,000 gallons

Station C is located on a rural highway of lower traffic volume than the other examples presented above. The independently owned station is branded with a major-national oil company and has been in operation for more than 3 years. The station owner had not negotiated an E85specific supply agreement during the time these data were collected. The station does have a street-visible E85 price sign. Pricing at the station has fluctuated with spot market ethanol prices and has ranged from the same price as gasoline to as much as \$.40 less than gasoline. Most often, a price of at least $\$ .20$ below gasoline has been maintained.

- Average monthly E85 sales (2006): At or less than 2,500 gallons

- Highest (summer) monthly sales (2006): At or less than 3,000 gallons

\section{Consumer Choice}

The consumer decision-making process to utilize E85 fuel in an FFV is similar to, but not as simple as, that for a gasoline vehicle, largely because of relative availability and limited awareness. There are a number of concrete steps in the E85 fueling process. The consumer must:

1. Buy an E85 vehicle, intentionally or otherwise

2. Recognize and understand the vehicle's E85 capabilities 
3. Choose to utilize E85

4. Locate an E85 station

5. Drive to the station and purchase E85.

Each of these steps creates an additional barrier to using E85 that is not present for gasoline.

With increased consumer awareness and E85 station availability, this process has become easier in Minnesota, but it is by no means ubiquitous.

\section{E85 Consumption in Minnesota}

In 2006, over 18 million gallons of E85 were consumed in Minnesota, an increase of more than $100 \%$ from 2005 sales (Figure 3). This represents roughly 150 gallons per FFV per year, which is perhaps $19 \%$ of an average vehicle's fuel use in a year $(12,000 \mathrm{miles} / 15 \mathrm{mpg})$.

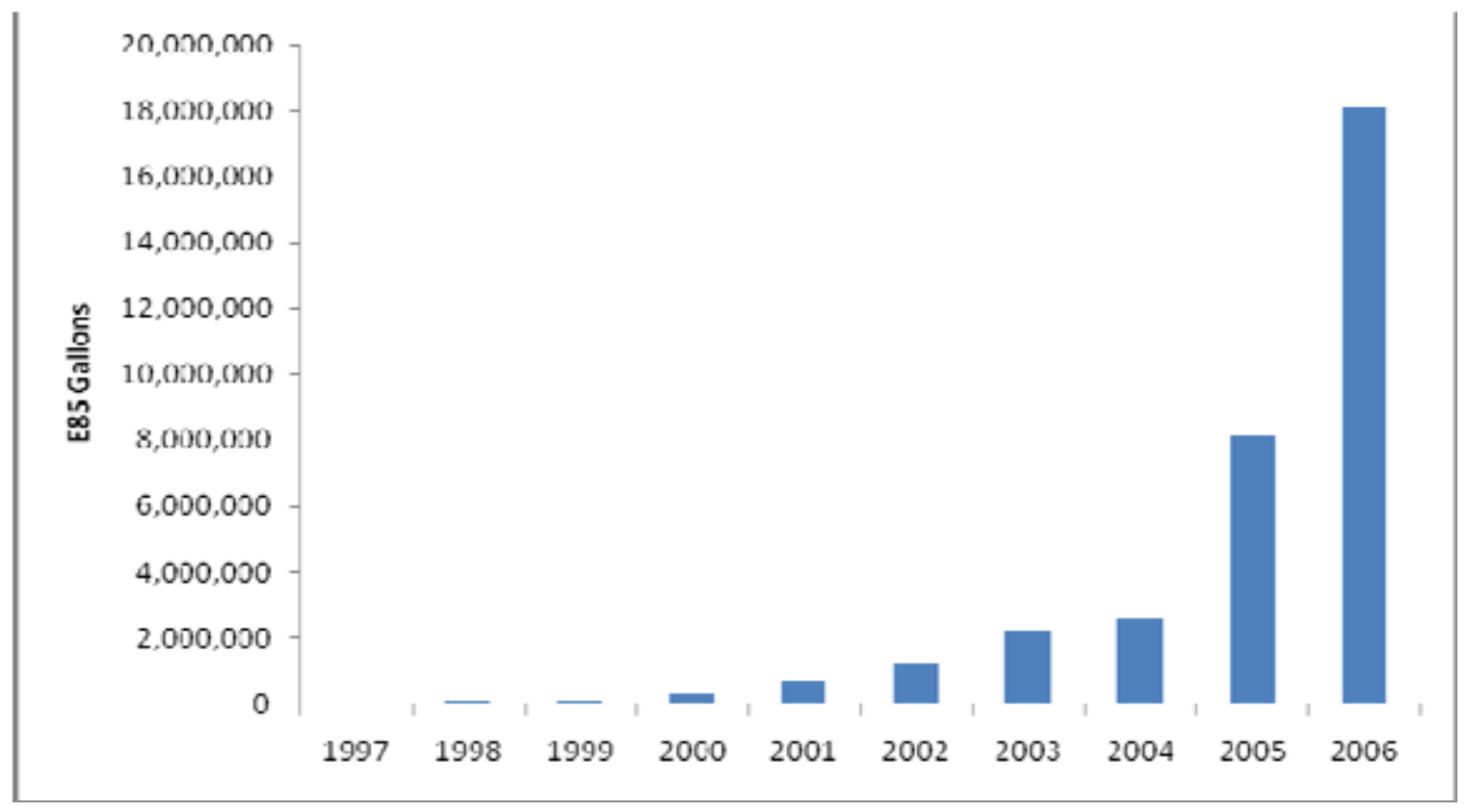

Figure 3. Minnesota E85 fuel sales, 1997-2006.

Source: Minnesota Department of Commerce "E85 Station Report," available www.commerce.state.mn.us.

E85 sales per station varied significantly from a low of 123 gallons to a high of almost 38,000 gallons per month in 2006, but averaged about 4,500 to 8,300 gallons in any individual month (Table 2). 
Table 2. 2006 E85 Station Volumes in Minnesota.

\begin{tabular}{|l|c|c|c|}
\hline \multicolumn{1}{|c|}{ Month } & E85 High & E85 Low & E85 Average \\
\hline January & 15,833 & 308 & 4,651 \\
\hline February & 14,711 & 352 & 4,427 \\
\hline March & 18,805 & 225 & 5,322 \\
\hline April & 24,523 & 314 & 6,193 \\
\hline May & 26,821 & 123 & 6,387 \\
\hline June & 28,294 & 208 & 6,918 \\
\hline July & 33,443 & 470 & 8,280 \\
\hline August & 37,771 & 540 & 8,272 \\
\hline September & 31,139 & 276 & 6,409 \\
\hline October & 26,399 & 298 & 6,187 \\
\hline November & 23,397 & 261 & 5,469 \\
\hline December & 21,337 & 285 & 5,079 \\
\hline \multicolumn{4}{|c|}{ Source: Minnesota Department of Commerce “E85 Station Report,” } \\
available www.commerce.state.mn. us.
\end{tabular}

\section{Report Objectives and Structure}

We used statistical analysis of an E85 station-level price and volume data set to assess which factors influence the volume of E85 sold by retail fuel stations in Minnesota and their relative importance, in order to provide further insight and suggestions for enhancing E85 program design and outreach. This information can be used to suggest strategies to fuel stations currently selling E85 and to identify which stations that do not sell E85 could be successful doing so.

A proprietary data set of monthly E85 prices and volumes by station was obtained from the Minnesota Department of Commerce (MNDOC). ${ }^{21}$ Monthly gasoline price data by station was purchased from the Oil Price Information Service (OPIS) and FFV data by zip code was sourced through R.L. Polk. All other data were obtained through publicly available sources as noted in the references.

Multivariate statistical analyses were then performed to provide insight into how various factors affect E85 sales. This analysis included sales from 1997-2006, and builds on a previous E85 study performed by two of the three authors, which included data through $2004 .^{22}$

In the following Data, Variables and Methods section we discuss the variables and hypotheses, analysis techniques, and study limitations. In the Multivariate Analysis Results section, we cover the basic analysis, brand analysis, and predictive equation. We conclude with a summary of the results, and provide recommendations for future analysis.

\footnotetext{
${ }^{21}$ The E85 survey data provided by the Minnesota Department of Commerce (MNDOC) are considered proprietary at the individual station level. However the American Lung Association of the Upper Midwest maintains a confidentiality agreement with the MNDOC as part of its role as the E85 project coordinator for Minnesota. Mike Taylor, a primary author of this report, is a former employee of the MNDOC who managed the E85 station surveys from 2000-2006, and acted as a subcontractor for the American Lung Association of the Upper Midwest in this analysis.

${ }^{22}$ The National Renewable Energy Laboratory (NREL) contracted with the American Lung Association of the Upper Midwest (ALAUM) in July 2007 to conduct this analysis, which is based on an unpublished University of Minnesota Master's thesis written by Lydia Dobrovolny, under advisement from Dr. Phil Bromiley, both primary authors in this report. A summary of the thesis is available online -

http://www1.umn.edu/iree/docs/sg p2 2005 final.doc.
} 


\section{Data, Variables, and Methods}

\section{Data Collection}

We examined the sale of E85 at fuel stations across Minnesota from late 1997-2006 using volumes and prices reported by station managers in a monthly E85 station survey distributed by the Minnesota Department of Commerce (MNDOC). ${ }^{23}$ Sales data are reported both voluntarily and through contractual loan obligations, and in any given month approximately $30 \%$ to $60 \%$ of stations respond to the survey. The spreadsheet obtained from the MNDOC included monthly E85 price and volume data for 353 E85 stations in Minnesota from late 1997 through 2006, from which a subset of data was extracted for analysis using these reported volumes.

If a station met any one of the following criteria, it was removed from the original data set and not included in the analysis:

- Stations that were not opened as of December 2006

- Stations with duplicate entries

- Stations with misidentified, or misaligned data

- Stations with no reported survey data

- Government stations not open to the public.

In addition, monthly data pairs were removed from the analysis if any of the following applied:

- The corresponding monthly E85 price or volume pair was missing

- Data was clearly miscoded or an outlier (e.g., recorded prices beyond any reasonable level, such as zero cents per gallon)

- The corresponding monthly gasoline price data was missing (see Gasoline Price below).

We did not have complete data on all the stations for all the variables considered, therefore, depending on which variables were in the model, the analyses had different numbers of usable observations. In the end, there were 95 stations with 4,126 useable data pairs, with approximately 67 of the stations and $66 \%$ of the price/volume pairs located in greater Minnesota, outside of the Twin Cities 9-county metropolitan area (Table 3).

Table 3. E85 Data Pairs by Region

\begin{tabular}{|l|l|l|}
\hline & Stations & Data Pairs \\
\hline Greater Minnesota & 67 & 2,751 \\
\hline Twin Cities & 28 & 1,375 \\
\hline Total & 95 & 4,126 \\
\hline
\end{tabular}

Data sources for other independent variables are discussed below.

\footnotetext{
${ }^{23}$ The American Lung Association of Minnesota maintains a data confidentiality agreement with the Minnesota Department of Commerce, which includes its subcontractors. Individual station data were obtained and analyzed, but are only published in the aggregate due to the proprietary considerations.
} 


\section{Variables and Hypotheses}

This study evaluates the impact (both directional and degree) of various factors such as station and location characteristics (explanatory/independent variables) on the sale volume of E85 (dependent variable) to draw recommendations about factors influencing the use of E85. The project team reviewed the previous E85 study and developed a list of variables for this analysis that included both previously used and additional variables.

\section{Dependent Variable: Volume of E85}

The models analyzed attempt to explain the number of gallons of E85 a station sold in a particular month.

\section{Explanatory/Independent Variables}

Since we wished to develop a predictive model rather than test a specific theory, we attempted to include a variety of reasonable explanatory variables. The models include a set of variables representing factors that may influence sales of E85. The previous study used several of these variables, as indicated in the summary of all variables in Table 4 (at the end of this Section). Our explanations for including the variables explain why it is reasonable to include them, rather than offering a strong theoretical justification. Information on each variable appears below.

\section{E85 Price}

We hypothesized that a higher price of E85 negatively influences the sales of E85. Data on monthly average E85 prices came from a monthly survey of station managers conducted by MNDOC. Most stations calculated the average monthly price by dividing total pump revenues by total gallons sold, although many stations only report the number and not the method.

\section{Gasoline Price}

We hypothesized that a higher price of regular gasoline should positively influence E85 salesthat is, when regular gasoline prices are high relative to E85 prices, FFV owners may purchase more E85. We purchased monthly data on station-level gas prices from the Oil Price Information Service (OPIS). Where OPIS provided data on the specific station selling E85 in a particular month, we used the price of regular gasoline for that specific station.

OPIS collects and aggregates data for stations across Minnesota (and the country) through vehicle fleet credit cards. OPIS does not provide data on stations where no one used such a card on a particular day. Of the 4,126 station-month E85 observations we used, we could calculate the actual regular gasoline price for 1,690 observations (41\%).

For the other stations, we used the statewide average price for regular gasoline as the gasoline price. We considered using the average price for the other stations in a station's zip code or county, but neither approach resulted in a significant reduction in usable sample size.

\section{E85 Price Difference $(\Delta)$}

The difference between the price of E85 and the price of regular gasoline should influence E85 sales. Models with these price differences are statistically similar to models that include both the E85 and regular prices themselves, but impose the additional constraint that changes in E85 price and regular gasoline price have the same influence. 


\section{Interaction of E85 Price and Regular Gasoline Price}

It makes sense that the reaction of consumers to a given change in price may depend on the level of the prices. We considered several ways to allow this in the model, including squares of E85 price and regular gasoline prices, and the square of the price difference. The interaction of the prices made the most sense: we allowed for the possibility that the influence of a change in E85 price varies with the level of the regular gasoline price by including a variable that equals the E85 price times the regular gasoline price.

\section{E85 Price Sign}

Nearly all gas stations have street-visible price marquee signs listing their fuel prices to the public. However, several stations that carry E85 do not display their E85 price. We hypothesize that displaying an E85 price sign positively influences E85 volume.

The price sign advertises that the station offers E85 and indicates its price relative to regular gasoline. E85 price sign data came from a price sign survey distributed by the MNDOC directly to E85 stations in August 2007, as well as follow-up phone calls and conversations with ALAUM staff. The data do not tell us when a station started displaying E85 prices. Our analysis assumes stations reporting signs in the survey have displayed E85 prices for just as long as they have sold E85. Seventy-two percent of the stations in the data set had signs. However, since the number of months a station had been reporting volume varied, only $57 \%$ of the station-months for which we had data covered stations displaying a sign.

\section{Station Age}

The number of FFV owners who know that a given station offers E85 should increase over time. Thus, the duration for which a station has sold E85 should positively influence the station's volume of E85 sales. The oldest E85 stations in Minnesota were open a little more than nine years and the youngest was open one month. We measured age in days.

\section{Number of Stations}

The demand for E85 should spread across the stations that sell E85. Thus, the number of stations within an area that sell E85 should negatively influence each station's E85 sales volume. We counted the number of stations within the same zip code, which ranged between one to four stations per zip code.

\section{Flexible Fuel Vehicles}

FFVs are necessary for utilizing E85 fuel. ${ }^{24}$ Consequently, the number of FFVs located within proximity to an E85 station should positively influence that station's E85 sales volume. We obtained data on the number of FFVs based on the number of cars with vehicle identification numbers (VIN) identifying them as an FFV. R.L. Polk, an automotive market data firm, provided data on such ownership by ZIP code in April 2006 and December 2006. The analysis assumes that the distribution of FFVs across zip codes has not changed substantially over time.

\footnotetext{
${ }^{24}$ Anecdotal conversations with ALAUM staff indicate that a small but unknown percentage of E85 sales involve consumers fueling with E85 in non-FFVs. These consumers may be enticed by the price differential or are motivated advocates. They ignore or misinterpret labels on the E85 dispenser.
} 


\section{Green Index}

While many stakeholders discuss E85 in environmental terms, they often take one of two very different positions. One position is that using E85 produces lower tailpipe emissions per mile driven than gasoline. The other position is that since FFVs are larger than the average vehicle, E85 use goes against an environmental emphasis on high efficiency vehicles to reduce overall fuel use. In addition, current ethanol production comes from corn which also raises concerns about levels of fertilizers, pesticides, and fossil fuels used in crop production. Consequently, the influence of environmental concern on E85 consumption is unclear.

The previous study used the proportion of environmental non-governmental organization membership in the general population by political district to indicate environmental orientation, and found a weak negative association with E85 volume. In this study, we use county data from the 2002 Minnesota governor's election as one potential indicator of environmental sentiment. In 2002, the Minnesota Green Party candidate received just over 2.2\% of the statewide vote (50,589 votes), the strongest Green Party showing in a statewide election. Eleven counties exceeded the statewide percentage, six of which were outside the metropolitan area. We included the number of votes for the Green Party gubernatorial candidate by county in the 2002 governor's election as reported by the Secretary of State's Office.

\section{Transportation Index}

Another potential indicator of support for E85 as an alternative transportation activity is the level of support for progressive transportation activities generally in the population. To assess this, we examined voting on a transportation initiative from the 2006 election, in which a statewide constitutional amendment ballot initiative asked:

Shall the Minnesota Constitution be amended to dedicate revenue from a tax on the sale of new and used motor vehicles over a five-year period, so that after June 30,2011 , all of the revenue is dedicated at least $40 \%$ for public transit assistance and not more than $60 \%$ for highway purposes?

The measure passed with $57 \%$ of the statewide vote. We use county-level voting patterns as reported by the Secretary of State's Office as a measure of support for transportation activities.

\section{Corn Production}

Some of the pressure to increase ethanol consumption comes from agricultural interests, in particular, corn producers. Potentially, such corn producers could purchase more E85 than other consumers. We included the county's percentage of average annual statewide corn production from 2000-2003 to reflect the concentration of corn producers. Data came from the U.S. Department of Agriculture. $^{25}$

\section{Ethanol Plant County and Adjacent Ethanol Plant County}

Some of the motivation for E85 usage may derive from the employment generated by ethanol plants that produce the ethanol for E85. Individuals living near ethanol production plants might see a positive impact of E85 consumption on their welfare and might be prone to buy E85. We included a variable indicating whether a gas station's county included an ethanol plant, and

\footnotetext{
${ }^{25}$ Significant station growth began in 2000 and data gaps existed in 2004-2006 data for certain counties.
} 
another variable indicating whether an adjacent county included a plant. At the end of 2006, 16 ethanol plants operated in Minnesota.

\section{Twin Cities}

Many social and political discussions in Minnesota distinguish between the Twin Cities area and the remainder of the state. The Twin Cities differs from the remainder of the state in a variety of ways including the number of individuals who commute to work across zip codes and counties, the physical size of zip code areas, average distances between E85 stations, pockets of exceedingly high population density, availability of public transport, etc.

We distinguish between counties in the Twin Cities metropolitan area (Anoka, Carver, Dakota, Hennepin, Ramsey, Scott, Sherburne, and Washington) and those in greater Minnesota.

\section{Population}

We controlled for population within zip code using population data from the U.S. Census Bureau.

\section{Income}

We controlled for differences in income using median household income data by zip code from the U.S. Census Bureau.

\section{Education}

We controlled for differences in education using the percentage of the population with a Bachelor's degree or higher by zip code from the U.S. Census Bureau.

Independent Variable Data Description

Table 4 describes the data obtained from the 4,126 observations and used for this analysis, as well as the probable influence of each variable on E85 sales volume. 
Table 4. E85 Analysis of Independent Variables and Statistical Information. Sources: [1] Minnesota Department of Commerce; [2] Oil Price Information Service; [3] American Lung Association of the Upper Midwest; [4] R.L. Polk; [5] U.S. Census Bureau; [6] Minnesota Secretary of State's Office; [7] U.S. Department of Agriculture; [8] Minnesota Department of Agriculture; [9] Calculation. Bold=variables included in previous study.

\begin{tabular}{|c|c|c|c|c|c|c|}
\hline Variables & Description & Mean & $\begin{array}{c}\text { Std. } \\
\text { Deviation }\end{array}$ & $\begin{array}{c}\text { Min. } \\
\text { Value }\end{array}$ & $\begin{array}{l}\text { Max. } \\
\text { Value }\end{array}$ & $\begin{array}{c}\text { Probable } \\
\text { Influence } \\
\text { on } \\
\text { Volume }\end{array}$ \\
\hline $\begin{array}{l}\text { E85 price } \\
\text { Source: }[1]\end{array}$ & $\begin{array}{l}\text { Monthly E85 prices by } \\
\text { station in \$/gallon }\end{array}$ & 1.640 & 0.396 & 0.6 & 2.98 & - \\
\hline $\begin{array}{l}\text { Gasoline } \\
\text { price } \\
\text { Source: [2] }\end{array}$ & $\begin{array}{l}\text { Monthly regular } \\
\text { gasoline prices by } \\
\text { station in } \$ / \text { gallon }\end{array}$ & 1.868 & 0.497 & 0.901 & 3.279 & + \\
\hline $\begin{array}{l}\text { Percent Price } \\
\text { Difference } \\
\text { Source: [9] }\end{array}$ & $\begin{array}{l}{[(\mathrm{E} 85 \text { price }- \text { regular }} \\
\text { gasoline price }) / \mathrm{E} 85 \\
\text { price }] * 100\end{array}$ & - & - & - & - & - \\
\hline $\begin{array}{l}\text { Interaction of } \\
\text { E85 and } \\
\text { Gasoline Price } \\
\text { Source: }[1],[2]\end{array}$ & $\begin{array}{l}\text { E85 price * gasoline } \\
\text { price }\end{array}$ & 3.252 & 1.646 & 0.541 & 9.03 & \\
\hline $\begin{array}{l}\text { E85 price } \\
\text { sign } \\
\text { Source: }[1],[3]\end{array}$ & $\begin{array}{l}1=\text { street sign showing } \\
\text { E85 price } \\
0=\text { no street sign } \\
\text { showing E } 85 \text { price }\end{array}$ & 0.574 & 0.495 & 0 & 1 & + \\
\hline $\begin{array}{l}\text { Station age } \\
\text { Source: [1] }\end{array}$ & \# days selling E85 & 971.1 & 755.7 & 0 & 3348 & + \\
\hline $\begin{array}{l}\text { Number of } \\
\text { stations } \\
\text { Source: [9] }\end{array}$ & $\begin{array}{l}\text { \# of stations in station's } \\
\text { zip code }\end{array}$ & 1.2 & 0.4 & 1 & 4 & - \\
\hline $\begin{array}{l}\text { FFVs } \\
\text { Source: [4] }\end{array}$ & $\begin{array}{l}\text { \# of FFVs in station's } \\
\text { zip code }\end{array}$ & 349.0 & 297 & 3 & 1244 & + \\
\hline $\begin{array}{l}\text { (FFVs) }^{2} \\
\text { Source: [4] }\end{array}$ & $\begin{array}{l}\text { (\# of FFVs in station's } \\
\text { zip code) }\end{array}$ & 210,205 & 325,409 & 9 & $1,546,292$ & - \\
\hline $\begin{array}{l}\text { Green } \\
\text { Source: [6] }\end{array}$ & $\begin{array}{l}2002 \text { Green Party } \\
\text { governor votes in } \\
\text { station's county }\end{array}$ & 0.0177 & 0.0089 & 0.0066 & 0.0446 & \\
\hline $\begin{array}{l}\text { Transportation } \\
\text { Source [6] }\end{array}$ & $\begin{array}{l}\text { Transportation funding } \\
\text { votes in station's } \\
\text { county }\end{array}$ & 0.5641 & 0.596 & 0.3861 & 0.6391 & \\
\hline $\begin{array}{l}\text { Corn } \\
\text { Production } \\
\text { Source: [7] }\end{array}$ & $\begin{array}{l}\% \text { state corn production } \\
\text { in station's county }\end{array}$ & 0.015 & 0.011 & 0 & 0.039 & + \\
\hline $\begin{array}{l}\text { Ethanol in } \\
\text { county } \\
\text { Source: [8] }\end{array}$ & $\begin{array}{l}1=\text { Ethanol plant } \\
\text { located in same county } \\
0=\text { No ethanol plant } \\
\text { located in county }\end{array}$ & 0.286 & 0.452 & 0 & 1 & + \\
\hline
\end{tabular}




\begin{tabular}{|c|c|c|c|c|c|c|}
\hline $\begin{array}{l}\text { Ethanol in } \\
\text { adjacent } \\
\text { county } \\
\text { Source: [8] }\end{array}$ & $\begin{array}{l}1=\text { Ethanol plant } \\
\text { located in adjacent } \\
\text { county } \\
0=\text { No ethanol plant } \\
\text { located in adjacent } \\
\text { county }\end{array}$ & 0.562 & 0.496 & 0 & 1 & + \\
\hline $\begin{array}{l}\text { Twin Cities } \\
\text { Source: }[1]\end{array}$ & $\begin{array}{l}1=\text { in Twin Cities } 8- \\
\text { county area } \\
0=\text { outside in Twin } \\
\text { Cities } 8 \text {-county area }\end{array}$ & 0.333 & 0.471 & 0 & 1 & \\
\hline $\begin{array}{l}\text { Population } \\
\text { Source: [5] }\end{array}$ & $\begin{array}{l}\text { Population in station's } \\
\text { zip code }\end{array}$ & 15,760 & 11,613 & 226 & 46,454 & \\
\hline $\begin{array}{l}\text { Income } \\
\text { Source: [5] }\end{array}$ & $\begin{array}{l}\text { Median household } \\
\text { income }(\$) \text { in station's } \\
\text { zip code }\end{array}$ & 45,760 & 12,019 & 25,662 & 77,818 & \\
\hline $\begin{array}{l}\text { Education } \\
\text { Source: [5] }\end{array}$ & $\begin{array}{l}\text { \% population w/at least } \\
\text { a Bachelor's degree in } \\
\text { station's zip code }\end{array}$ & 0.146 & 0.063 & 0.028 & 0.423 & \\
\hline
\end{tabular}

\section{Analysis Techniques}

The details of the model specification depend on a variety of assumptions and judgments about precisely what question the analysis should answer, as well as various technical issues. For example, a straight-forward regression analysis of monthly E85 volume versus the set of explanatory variables would explain differences across stations, and over time. A regression that included the previous month's sales volume would explain changes in volume for a given station over time.

We decided to use the random effects least squares regression method ("XT Reg"; equation 1). A simple regression estimates a model of the form:

$$
\mathrm{Y}_{\mathrm{i}, \mathrm{t}}=\mathrm{b}_{0}+\mathrm{b}_{1} \mathrm{X} 1_{\mathrm{i}, \mathrm{t}}+\mathrm{b}_{2} \mathrm{X} 2_{\mathrm{i}, \mathrm{t}}+\mathrm{e}_{\mathrm{i}, \mathrm{t}}
$$

where $Y_{i, t}$ is the variable being explained for unit $\mathrm{i}$ in time $\mathrm{t}$ (in our case, volume for a particular gas station in a particular month), $\mathrm{b}_{0}, \mathrm{~b}_{1}$, and $\mathrm{b}_{2}$ are coefficients to be estimated, $\mathrm{X} 1_{\mathrm{i}, \mathrm{t}}$ and $\mathrm{X} 2_{\mathrm{i}, \mathrm{t}}$ are explanatory variables for unit $i$ at time $t$, and $e_{i, t}$ is a random error term for unit $i$ at time $t$. The $\mathrm{e}_{\mathrm{i}, \mathrm{t}}$ term allows for the fact that the model does not predict $\mathrm{Y}$ perfectly. The estimation then finds the values for $b_{0}, b_{1}$, and $b_{2}$ that minimize the sum of the $e_{i, t}$ 's squared. Many of the other assumptions of the estimation deal with the distribution of $\mathrm{e}_{\mathrm{i}, \mathrm{t}}$.

A common modification of the model for data on multiple units over time is to allow each unit to have a different intercept, or $\mathrm{b}_{0}$. This lets a station have consistently higher or lower $\mathrm{Y}$ (volume) over time (relative to the average). This is written as:

$$
\mathrm{Y}_{\mathrm{i}, \mathrm{t}}=\mathrm{b}_{0}+\mathrm{b}_{1} \mathrm{X} 1_{\mathrm{i}, \mathrm{t}}+\mathrm{b}_{2} \mathrm{X} 2_{\mathrm{i}, \mathrm{t}}+\mathrm{u}_{\mathrm{i}}+\mathrm{e}_{\mathrm{i}, \mathrm{t}}
$$

The $u_{i}$ is a variable that has a different value for each station, $i$. To let us estimate station-specific factors that do not vary over time, we use a form of estimation that assumes the $u_{i}$ are uncorrelated with the included X's and are drawn from a random population. This is referred to 
as a random effects time series-cross sectional model. Basically, it assumes the coefficients on the X's are constant for all the stations, but allows each station to have a different level.

If we only had one X variable with four different units, the equation would look like Figure 4.

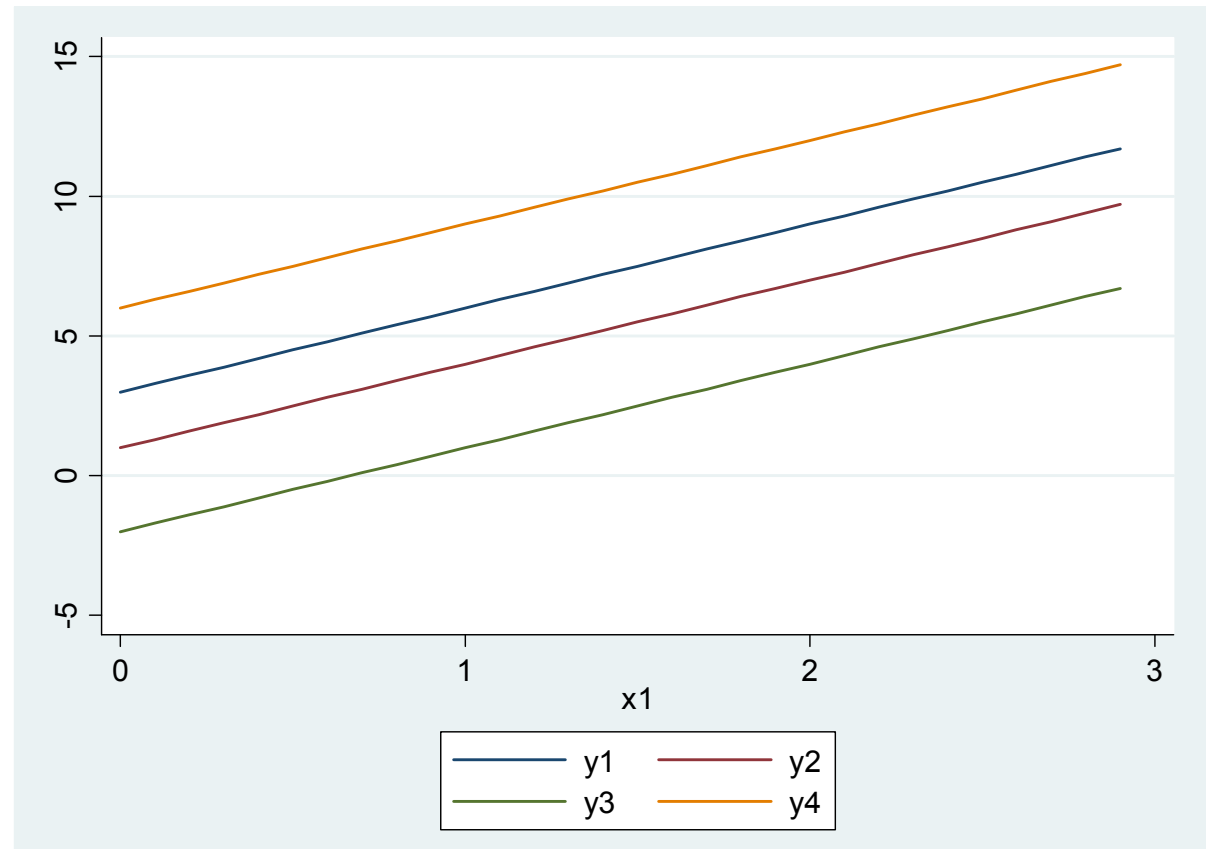

Figure 4. Random effects time series cross sectional model example.

Here, each $\mathrm{Y}$ has a different intercept (value of $\mathrm{Y}$ when $\mathrm{X}=0$ ), but the same slope. This is roughly what time-series cross sectional analysis allows; each station can have a different intercept. In the gas station data, the different intercepts reflect the numerous stable factors that influence sales volume that we have been unable to include (e.g., details of location, station size and facilities, station management, etc.).

We estimated the model for levels of price (E85 and regular gasoline price separately) and the percentage price difference between E85 and regular gasoline.

We used the xtreg procedures from the STATA 10 statistical package for estimation. The number of parameters versus observations estimated falls well below the 1 parameter per 10 observations ratio used as a guideline for when the number of parameters should be a cause for concern. 


\section{Multivariate Analysis Results}

\section{Basic Analysis of Monthly E85 Volumes}

We estimated two variations on the model: (1) with just price variables, and (2) with percent price difference between E85 and regular gasoline. Table 6 presents the results.

Econometricians use various indices for fit and model selection. The best indices trade off quality of fit versus the number of parameters estimated. Among the most commonly used are AIC (Akaike Information Criterion) and BIC (Bayesian Information Criterion), which both provide similar results in this analysis. BIC has been shown particularly effective in selecting correct models in simulated data. Lower BIC indicates a more desirable model.

The model with prices levels (1) has substantially better results by the BIC criterion than the models with price differences (2). The reason is readily apparent in the coefficient estimates. The price difference $([(\mathrm{E} 85$ price - regular gasoline price $) / \mathrm{E} 85$ price $] * 100)$ assumes a change in E85 price has the same influence with opposite sign as a change in the regular gasoline price. However, the coefficient estimates in Table 2 indicate a change in the regular gasoline price has a dramatically different influence than a change in the E85 price.

The results agree substantially with the results from the original paper, where comparable. Key findings that explain E85 sales include:

\section{Prices}

The coefficient on the interaction term in the price level equation (1) is statistically insignificant. However, the coefficient is our best estimate of the influence of the interaction, and so may be used for predictive purposes.

With the linear and interaction terms in the model, the change in volume for a one dollar increase in $\mathrm{E} 85$ price is:

$$
\mathrm{dVolume}=-7,179+106 * \text { regular gasoline Price }
$$

For example, at the mean E85 price in the sample (\$1.64) and mean regular gasoline price in the sample (\$1.86), a $\$ 1$ increase in the price of E85 on average results in:

$$
\text { dVolume }=-7,179+106 * 1.86=-6,982 \text { gallons }
$$

In this study we measure price in dollars. Naturally, a $1 \notin$ change in E85 price is far more likely and would result in -69.82 gallons change.

Qualitatively, the negative coefficient on the E85 price means higher prices result in lower value, but the positive sign on the interaction means the reduction in volume is smaller when the price of regular gasoline is high.

Table 5 shows the change in volume for \$1 change in E85 price at the average prices for each year, which indicates a higher predicted impact at higher prices. 
Table 5. Impact of E85 price increase on volume sales by E85 and gasoline prices.

\begin{tabular}{|c|c|c|c|}
\hline Year & $\begin{array}{c}\text { Average } \\
\text { E85 Price }\end{array}$ & $\begin{array}{c}\text { Average } \\
\text { Regular } \\
\text { Gasoline Price }\end{array}$ & $\begin{array}{c}\text { Effect of \$1 increase } \\
\text { in the price of E85 }\end{array}$ \\
\hline 1997 & 1.37 & 1.47 & $-7,023$ \\
\hline 1998 & 1.55 & 1.69 & $-7,000$ \\
\hline 1999 & 1.55 & 1.75 & $-6,994$ \\
\hline 2000 & 1.63 & 1.87 & $-6,981$ \\
\hline 2001 & 1.63 & 1.90 & $-6,978$ \\
\hline 2002 & 1.82 & 2.11 & $-6,955$ \\
\hline 2003 & 1.87 & 2.15 & $-6,951$ \\
\hline 2004 & 2.04 & 2.41 & $-6,924$ \\
\hline 2005 & 2.07 & 2.44 & $-6,920$ \\
\hline
\end{tabular}

The model with percent price differences (2) gives a similar set of conclusions, but the interaction term is statistically significant here. This picks up the difference in magnitude between the coefficient on regular gasoline price and the coefficient on E85 in equation (1).

Higher prices reduce volume, but the reduction is lower when the regular gasoline price is high.

Table 6. Explaining Monthly Volume E85 - Basic Results. Standard errors are in parentheses.

\begin{tabular}{|l|c|c|}
\hline \multicolumn{1}{|c|}{ Explanatory Variables } & Dependent Variable: Monthly E85 sales volume \\
\hline E85 price & $-7,179(502.232)^{* * *}$ & \\
\hline Regular Gasoline price & $10,735(409)^{* * *}$ & \\
\hline$\%$ Price Difference E85 vs. & & $-116(4.38)^{* * *}$ \\
Regular Gas & $106(178.9)$ & $1,362(29.2)^{* * *}$ \\
\hline Interaction of E85 price and & & \\
\hline Regular Gasoline Price & $2,087(747.7)^{* *}$ & $2,106(758)^{* *}$ \\
\hline Twin Cities & $-381.0(134.7)^{* *}$ & $-300(139)^{*}$ \\
\hline Number of Stations in Zip Code & $8.057(2.220)^{* * *}$ & $8.136(2.25)^{* * *}$ \\
\hline FFVs & $-0.005(0.002)^{* *}$ & $-0.005(0.002)^{* *}$ \\
\hline (FFVs) ${ }^{*}$ & $-30,276(22,705)$ & $-27,069(23,036)$ \\
\hline Green & $266.1(3,466)$ & $-74.0(3,514)$ \\
\hline Transportation Vote & $0.011(0.032)$ & $0.005(0.033)$ \\
\hline Population & $-0.004(0.026)$ & $-0.006(0.027)$ \\
\hline Income & $800 \dagger(426)$ & $829 \dagger(432)$ \\
\hline Price Sign & $94.6(490.9)$ & $107.8(497.5)$ \\
\hline Ethanol Plant in County & $396.6(500.7)$ & $352(508)$ \\
\hline Adj. Ethanol Plant County & $9,175(23,464)$ & $13,154(23,794)$ \\
\hline Corn Production & $1.258(0.193)^{* * *}$ & $1.184(0.197)^{* * *}$ \\
\hline Station Age in days & $2,330(4,104)$ & $2,337(4,165)$ \\
\hline Education & 4126 & 4126 \\
\hline Observations & 198 & 198 \\
\hline Number of stations & 76,328 & 76,579 \\
\hline BIC & & \\
\hline
\end{tabular}

$* \mathrm{p}<0.05, * * \mathrm{p}<0.01, * * * \mathrm{p}<0.001, \dagger \mathrm{p}<0.1$ 


\section{Metropolitan Location}

Stations in the Twin Cities sold substantially higher volumes than those in greater Minnesota. The coefficient on the Twin Cities variable is statistically significant and positive. Being located in the metropolitan area increased sales by approximately 2,087 gallons per month.

\section{Number of Stations in Zip Code}

The number of stations located in a zip code was statistically significant and negative. Each additional station in a station's zip code lowers volume by 381 gallons per month.

\section{Local FFV Ownership}

The number of FFVs located in the same zip code as the station positively influenced E85 sales. For every additional vehicle located in the same zip code, sales increased by eight gallons per month. The square of FFVs is negative, implying that the marginal benefit from additional FFVs in the region is less for those in regions with high numbers of FFVs.

This FFV influence continued up to around 806 vehicles per zip code, as indicated by running the model with vehicle limits by zip code, beyond which the positive effects diminish so that no additional increase in E85 sales volume was observed. However, only a limited number of zip codes had more than 806 FFVs, as shown in Figure 5.

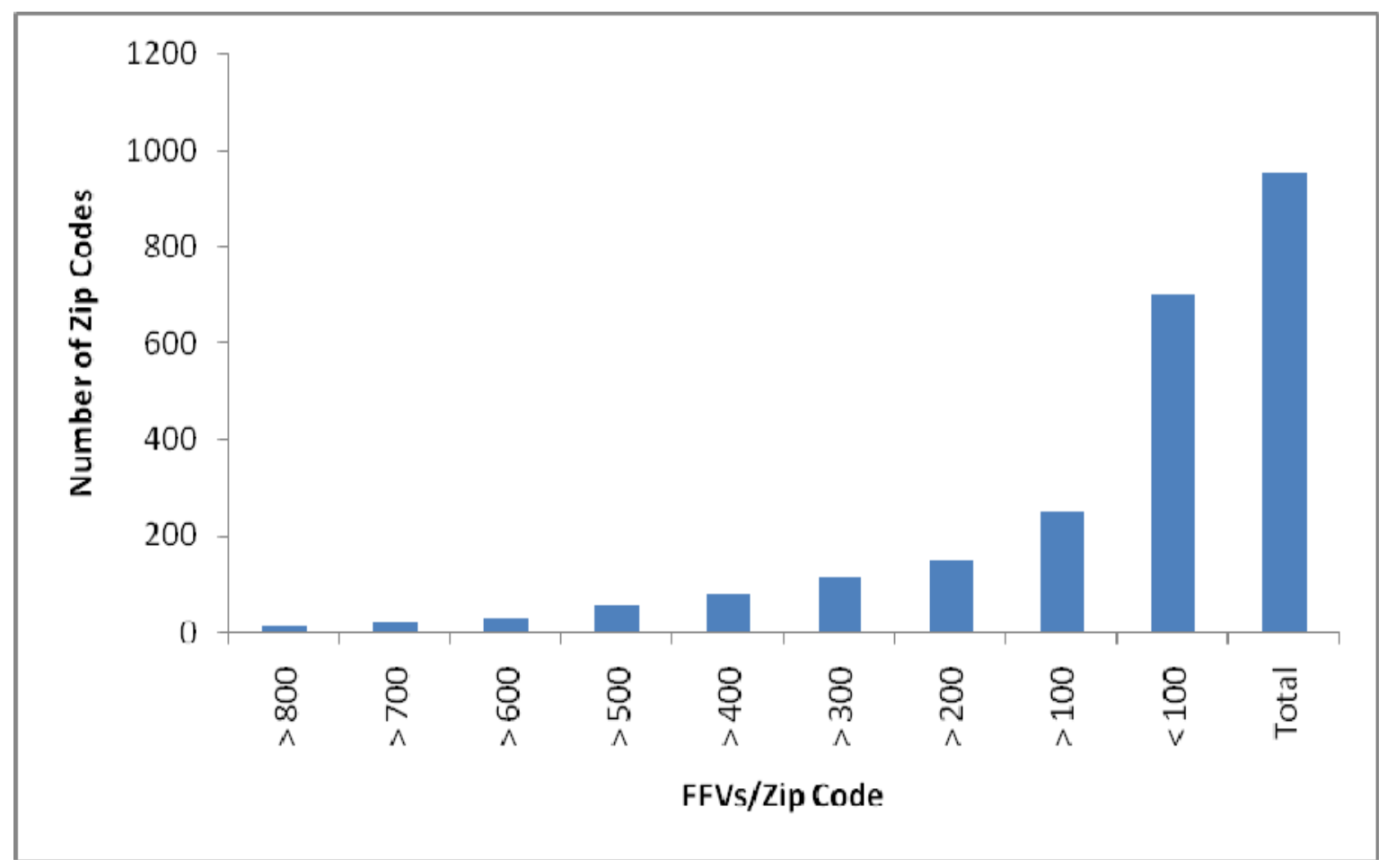

Figure 5. Number of zip codes by FFV count in Minnesota. Source: R. L. Polk

\section{Green Vote}

The analysis found no statistically significant influence of Green Vote on E85 sales.

\section{Transportation Vote}

The analysis found no statistically significant influence of the Transportation Vote on E85 sales. 


\section{Population}

The analysis found no statically significant influence of population on E85 sales.

\section{Income}

The analysis found no statistically significant influence of income levels on E85 sales. ${ }^{26}$

\section{Sign at the Station}

Visible price sign marquees at E85 stations positively influence the volume of E85 sold by approximately 800 gallons per month.

\section{Proximity to an Ethanol Plant}

The analysis found no statistically significant influence on E85 sales of being in or next to a county with an ethanol plant.

\section{Corn Production}

Analysis found no statistically significant influence of levels of corn production on E85 sales.

\section{Duration of Sales}

The duration for which the station has been selling E85 positively influences sales volume. The coefficient estimates are positive and statistically significant in both models. Each additional day of selling E85 adds about 1.3 gallons to the total.

\section{Education}

We found no evidence that high levels of education influenced E85 sales.

\section{Results Summary}

To summarize the results, we have strong evidence that the following influence a station's E85 volume:

1. Prices of E85 and regular gasoline

2. The number of stations selling E85 in the zip code

3. Location in the Twin Cities

4. The number of FFVs in the station's zip code

5. Displaying a sign announcing the E85 price

6. The duration over which the station has sold E85.

\section{Brand Analysis of Monthly E85 Volumes}

We also investigated whether station branding influences E85 sales. We grouped stations according to station brand name into Unbranded, Major Brand, Other Brand, or Holiday Brand categories (See Table 7). The coefficients on Major, Other Brands, and Holiday represent the number of E85 gallons per month more or less that kind of station sells on average relative to the Unbranded stations. ${ }^{27}$ Holiday was included in the Other Brands category as well as its own.

\footnotetext{
${ }^{26}$ Note that all of these estimates control for the other variables in the model. For example, if high income resulted in more FFV purchases, this would not show up as an income effect because we included the number of FFVs as an explanatory variable.

27 This bundling of the data does not take into account brand adjustments that began in 2006.
} 
Table 7. E85 Station Groupings.

\begin{tabular}{|l|c|c|c|}
\hline \multicolumn{1}{|c|}{ Major } & Other Brand & Unbranded & Holiday \\
\hline BP & Speedway & Farstad & Holiday \\
\hline CITGO & SuperAmerica & Freedom & \\
\hline Conoco & Kwik Trip & Unknown & \\
\hline Marathon Ashland & Cenex & Unbranded & \\
\hline Mobil & Holiday & & \\
\hline Philips 66 & & & \\
\hline Shell & & & \\
\hline Sinclair & & & \\
\hline
\end{tabular}

To describe how sales of E85 vary across different kinds of stations, the model tested whether being a Major, Other Brand, or Holiday station type results in a discrete increase or decrease in volume compared to being Unbranded. The results of this analysis are presented in Table 8 .

Table 8. Effects of Kinds of Stations on Monthly Volumes of E85. Standard errors are in parenthesis.

\begin{tabular}{|l|c|c|}
\hline \multicolumn{1}{|c|}{ Explanatory Variables } & \multicolumn{2}{c|}{ Dependent Variable: Monthly E85 sales volume } \\
\hline E85 price & (1) With Price Levels & (2) With \% Price Difference \\
\hline Regular Gasoline price & $-9,560(479)^{* * *}$ & \\
\hline \% Price Difference E85 vs. Regular Gas & $8,233(395)^{* * *}$ & \\
\hline Interaction of E85 price \& Regular Gas & & $-113.2(4.04)^{* * *}$ \\
\hline Twin Cities & $1,068(171)^{* * *}$ & $1,049(29.6)^{* * *}$ \\
\hline Number of Stations in Zip Code & $1601(730)^{*}$ & $1545(733)^{*}$ \\
\hline FFVs & $-486.4(126)^{* * *}$ & $-492.3(128)^{* * *}$ \\
\hline FFVs) & $7.891(2.17)^{* * *}$ & $8.179(2.18)^{* * *}$ \\
\hline Green & $-0.00557(0.0017)^{* * *}$ & $-0.00570(0.0017)^{* * *}$ \\
\hline Transportation Vote & $-38,026(22,060)^{\dagger}$ & $-37,088^{\dagger}(22188)$ \\
\hline Population & $71.91(3373)$ & $106.9(3390)$ \\
\hline Income & $0.0218(0.031)$ & $0.0196(0.032)$ \\
\hline Price Sign & $-0.0129(0.026)$ & $-0.0167(0.026)$ \\
\hline Ethanol Plant County & $1,071(414)^{* *}$ & $1,085(417)^{* *}$ \\
\hline Adj. Ethanol Plant County & $153.3(478)$ & $218.7(480)$ \\
\hline Corn Production & $326.8(489)$ & $233.3(491)$ \\
\hline Station Age in days & $17,698(22,813)$ & $18,689(22,928)$ \\
\hline Education & $0.869(0.19)^{* * *}$ & $0.812(0.19)^{* * *}$ \\
\hline Major Brand & $1,123(3983)$ & $1,417(4007)$ \\
\hline Other Brand & $103.1(266)$ & $-1.142(271)$ \\
\hline Holiday Brand & $817.7(137)^{* * *}$ & $794.2(138)^{* * *}$ \\
\hline Observations & $3,768(149)^{* * *}$ & $3,895(147)^{* * * *}$ \\
\hline Number of stations & 4,126 & 4,126 \\
\hline BIC & 198 & 198 \\
\hline
\end{tabular}

${ }^{*} \mathrm{p}<0.05,{ }^{* *} \mathrm{p}<0.01,{ }^{* * *} \mathrm{p}<0.001,{ }^{\dagger} \mathrm{p}<0.1$ 
The analysis demonstrates:

- Holiday stations have significantly higher E85 sales than Major, Other, and Unbranded.

- Holding everything else constant, a Holiday station sells 3,768 more gallons per month than an Unbranded station.

- The Other Brands have significantly higher sales than Major and Unbranded.

- Holding everything else constant, an Other Brand sells 818 more gallons per month than an Unbranded.

- Major does not differ significantly from unbranded.

- Major and unbranded stations have the lowest volumes of E85 sales.

Reasons for these differences are difficult to discern and beyond the current scope of this study. It might be that branded stations simply sell more gas on average than the others, and as a result, also sell more E85. Alternatively, the branded stations may market E85 more than other brands or individual stations through signs, promotions, etc. However, without additional data on station-level monthly volume of regular gasoline sold, which is not publicly available, we cannot explain this phenomenon.

\section{Predictive Equation}

In examining the BIC figures for brand analysis (Table 8) versus the basic analysis (Table 6), we find the brand analysis has the lowest values, indicating that this model is the best overall model for explaining factors influencing sales of E85. Further, the model with levels of prices (1) has a lower BIC than the model with percent price difference (2). Thus, we will use the level of prices model (1) with brands to develop an equation to predict the monthly ethanol sales volumes for each station in this study based on the values of their significant parameters:

$$
\begin{aligned}
\text { Monthly Volume of Ethanol Sales }= & -9,560 *(\text { E85 price in dollars }) \\
& +8,233 *(\text { Regular gasoline price in dollars }) \\
& +1,068(\text { E85 price in } \$) *(\text { Regular gasoline price in } \$) \\
& +1,601 \text { if located in Twin Cities } \\
& -486 *(\text { Number of Stations Selling E85 in Zip code }) \\
& +7.89 * \text { (Average of } 2006 \text { and } 2007 \# \text { of FFVs }) \\
& -.0056 *(\text { Average of } 2006 \text { and } 2007 \# \text { of FFVs })^{2} \\
& +1,071 \text { if has a sign displayed at station } \\
& +.869 * \text { (Days since started selling E85) } \\
& +818 \text { if Other brand } \\
& +3,768 \text { if Holiday brand }
\end{aligned}
$$

We did not include statistically insignificant variables in the predictive equation. Since the Green variable was statistically insignificant in the first estimates and only marginally significant in this price level model with brands, we did not include it.

\section{Additional Analysis}

We also examined the rate of change in prices. Table 9 presents estimates of the model including both the brand variables, and the percent change in E85 and regular gasoline prices from the previous month to current month. 
Table 9. Allowing for Change in Prices. Standard errors are in parenthesis.

\begin{tabular}{|c|c|c|}
\hline \multirow[b]{2}{*}{ Explanatory Variables } & \multicolumn{2}{|c|}{ Dependent Variable: Monthly E85 sales volume } \\
\hline & (1) With Price Levels & (2) With \% Price Difference \\
\hline E85 price & $-11,913(525)^{* * *}$ & \\
\hline Regular gasoline price & $10,027(435)^{* * *}$ & \\
\hline $\begin{array}{l}\% \text { Price Difference E85 vs. Regular } \\
\text { Gas }\end{array}$ & & $-133.8(4.72)^{* * *}$ \\
\hline $\begin{array}{l}\text { \% Change in E85 price from previous } \\
\text { month }\end{array}$ & $60.87(5.91)^{* * *}$ & $53.65(6.15)^{* * *}$ \\
\hline $\begin{array}{l}\text { \% Change in regular gasoline price } \\
\text { from previous month }\end{array}$ & $-87.41(7.09)^{* * *}$ & $-82.40(7.38)^{* * *}$ \\
\hline $\begin{array}{l}\text { Interaction of E85 price and Regular } \\
\text { Gas }\end{array}$ & $1,174(179)^{* * *}$ & $1098(33.4)^{* * *}$ \\
\hline Twin Cities & $1,890 *(791)$ & $1,731(787)^{*}$ \\
\hline Number of Stations in Zip Code & $-675.3(132)^{* * *}$ & $-669.8(136)^{* * *}$ \\
\hline FFVs & $8.309(2.26)^{* * *}$ & $8.662(2.24)^{* * *}$ \\
\hline$(\mathrm{FFVs})^{2}$ & $-0.00542 * *(0.0018)$ & $-0.00555(0.0017)^{* *}$ \\
\hline Green & $-36,456(24587)$ & $-37,028(24,508)$ \\
\hline Transportation Vote & $1,752(3639)$ & $1,303(3,627)$ \\
\hline Population & $0.0219(0.032)$ & $0.0174(0.032)$ \\
\hline Income & $-0.0396(0.029)$ & $-0.0434(0.029)$ \\
\hline Price Sign & $963.1(457)^{*}$ & $959.1(454)^{*}$ \\
\hline Ethanol Plant in County & $439.2(504)$ & $522.7(502)$ \\
\hline Ethanol Plant in Adjacent County & $421.7(536)$ & $296.0(534)$ \\
\hline Corn Production & $18,251(25294)$ & $14,805(25165)$ \\
\hline Station Age in days & $0.597(0.20)^{* *}$ & $0.544(0.20)^{* *}$ \\
\hline Education & $6,814(4672)$ & $7,265(4643)$ \\
\hline Major Brand & $540.7(321)^{\dagger}$ & $200.9(326)$ \\
\hline Other Brand & $689.8(144)^{* * *}$ & $656.6(146)^{* * *}$ \\
\hline Holiday Brand & $3,764(151)^{* * *}$ & $3,904(150)^{* * *}$ \\
\hline Observations & 3,505 & 3,505 \\
\hline Number of stations & 162 & 162 \\
\hline BIC & 64,091 & 64,324 \\
\hline
\end{tabular}

$* \mathrm{p}<0.05, * * \mathrm{p}<0.01, * * * \mathrm{p}<0.001,{ }^{\dagger} \mathrm{p}<0.1$

First, note that the inclusion of these change variables resulted in a substantial improvement in the BIC, from 75,755 to 64,091. The change in price variables are both highly significant. Fractional change in E85 price positively influences E85 volume. Fractional change in regular gasoline price negatively influences E85 volume.

This suggests some stability in buyer behavior. If E85 price is at a given level for several months, then the change variable equals zero, and the price times its large negative coefficient influences volume. But if price has just risen, the positive coefficient on change in price will result in the volume dropping less than would occur if the price stays at the new level.

Likewise, the effect of level of regular gas price is positive on E85 volume, but the change in regular gas price is negative. Suppose the E85 price remained constant and the regular gas price 
increased. If so, the regular price increase will positively influence E85 sales. However, in the month the price rises, the negative coefficient on change in price will mitigate the volume increase in E85. Again, after that month, the price change becomes zero, and the full effect of higher regular prices increases E85 sales above what they were the month of the change.

We did not include this model in the predictive equation since the modifications address shortterm dynamics rather than overall volumes.

\section{Study Limitations}

While these results provide insight into the success factors driving E85 sales, there are limitations to this analysis. Geographic effects (e.g. station proximity to highway), competition from other stations selling E85 nearby (limited density across the data sample), or consumption from vehicle fleet user groups located near an outlet were not controlled. In addition, this analysis was conducted at the macro level and we were unable to obtain station-level gasoline sales data to test whether stations that sell larger volumes of gasoline also sell corresponding larger volumes of E85, relative to other stations. 


\section{Conclusion}

Statistically speaking, the following factors were found to positively increase E85 volume sales, (based on Table 6, Column 1):

- Decreasing E85 or increasing regular gasoline prices, or the price difference therein

- Locating stations in a Twin Cities metropolitan county

- Locating stations in a zip code with greater numbers of FFVs

- Locating stations in a zip code with fewer stations selling E85

- Including a price sign at the station

- Selling E85 for longer time periods

- Selling E85 at a branded, but non-major, station.

- Consumer attitudes towards "green" issues and progressive transportation issues, as represented by the data on voting patterns used for this study, were found to have no statistical significance for E85 sales. This was also the case for the two consumer characteristics studied - income level and education.

Obviously, no one has control of all these factors. E85 program managers and station owners might be able to increase E85 consumption through the following:

- Influencing E85 prices. The lower the E85 price, the more E85 that will be sold. Efforts should be made to keep E85 prices competitive with gasoline through:

- Direct supply arrangements with ethanol plants or purchase aggregation cooperatives.

- Long-term pricing understandings with station owners that maintain a specific monetary or percentage difference below gasoline. Working with the right person who understands the long-view is as important as the right station.

- Locating stations in areas with high FFV populations (this does not necessarily preclude rural areas who may have medium-sized towns with sufficient numbers of FFVs)

- Locating stations in metropolitan areas

- Including an E85 sign as a requirement for funding

- Emphasizing to new retailers that sales increase with age, so retailers need to make a longterm commitment

- Working with state or regional brands to encourage E85 sales. Actions might include corporate E85 pricing policies, ethanol supply agreements, brand differentiation by E85 (or a branded version of E85), installing E85 in multiple stations at once (allowing greater combined promotion), and generally getting top management support for E85 promotion.

The analysis team has several questions that merit further study: 
- Are good gas stations automatically good E85 stations? It may be that high volume stations that adopt E85 are the high volume E85 distributors. Data on gasoline consumption by station is unavailable broadly, but could potentially be obtained through brand chains, such as Holiday or Kwik Trip, for a smaller sample study. This would help determine if a highvolume gas station is also a high volume E85 station, potentially capturing multiple variable influences in one characteristic.

- What are the costs and benefits of installing E85 equipment at certain E85 stations? Different stations have higher or lower costs to install equipment (new versus retrofit, urban versus rural, one-off versus multiple, etc.). What is the optimal cost with the corresponding benefit? 


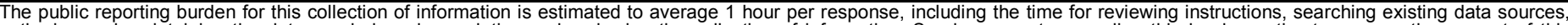

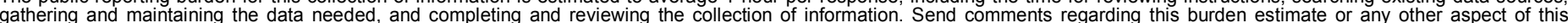

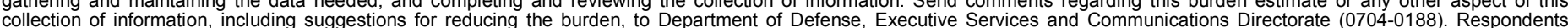

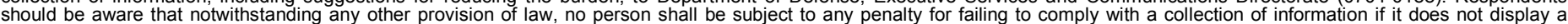

should be aware that notwithstanding

PLEASE DO NOT RETURN YOUR FORM TO THE ABOVE ORGANIZATION.

\begin{tabular}{l|l|l|l} 
1. REPORT DATE $(D D-M M-Y Y Y Y)$ & 2. & REPORT TYPE & 3. DATES COVERED (FrOm - TO)
\end{tabular}

July 2008

Subcontract Report

4. TITLE AND SUBTITLE

Statistical Analysis of the Factors Influencing Consumer Use of E85

5a. CONTRACT NUMBER

DE-AC36-99-GO10337

5b. GRANT NUMBER

5c. PROGRAM ELEMENT NUMBER

6. AUTHOR(S)

P. Bromiley: University of California, Irvine

T. Gerlach, K. Marczak, M. Taylor, and L. Dobrovolny: American

Lung Association of the Upper Midwest

5d. PROJECT NUMBER

NREL/SR-540-42984

5e. TASK NUMBER

FC08.0032

5f. WORK UNIT NUMBER
7. PERFORMING ORGANIZATION NAME(S) AND ADDRESS(ES)

American Lung Association of the Upper Midwest

St. Paul, Minnesota
8. PERFORMING ORGANIZATION REPORT NUMBER

AEV-7-77396-01

9. SPONSORING/MONITORING AGENCY NAME(S) AND ADDRESS(ES)

National Renewable Energy Laboratory

1617 Cole Blvd.

Golden, CO 80401-3393

10. SPONSOR/MONITOR'S ACRONYM(S)

NREL

11. SPONSORING/MONITORING AGENCY REPORT NUMBER NREL/SR-540-42984

12. DISTRIBUTION AVAILABILITY STATEMENT

National Technical Information Service

U.S. Department of Commerce

5285 Port Royal Road

Springfield, VA 22161

13. SUPPLEMENTARY NOTES

NREL Technical Monitor: Paul Bergeron

14. ABSTRACT (Maximum 200 Words)

Evaluating the sales patterns of E85 retail outlets can provide important information about consumer behavior regarding E85, locating future E85 fueling infrastructure, and developing future alternative fuel policies and programs.

\section{SUBJECT TERMS}

E85; infrastructure; Minnesota; E85 pricing; ethanol plant; fueling stations

16. SECURITY CLASSIFICATION OF:
\begin{tabular}{|l|l|l|}
\hline $\begin{array}{c}\text { a. REPORT } \\
\text { Unclassified }\end{array}$ & $\begin{array}{c}\text { b. ABSTRACT } \\
\text { Unclassified }\end{array}$ & $\begin{array}{l}\text { c. THIS PAGE } \\
\text { Unclassified }\end{array}$ \\
\hline
\end{tabular}

\begin{tabular}{l|l} 
17. LIMITATION & 18. $\begin{array}{l}\text { NUMBER } \\
\text { OF PAGES } \\
\text { OF ABSTRACT } \\
\text { UL }\end{array}$ \\
\end{tabular}

19a. NAME OF RESPONSIBLE PERSON

19b. TELEPHONE NUMBER (Include area code) 